\title{
Effect of Honey on Oxidative Stress in the Brain Tissue of Sleep Deprived Rats
}

\author{
10.0. Akintoye, ${ }^{1}$ A.J. Ajibare, ${ }^{1}$ O.A. Fabunmi, ${ }^{* 2}$ A.O. Asuku, ${ }^{3}$ R.A. Tajudeen. \\ ${ }^{1}$ Department of Physiology, College of Medicine, Ekiti State University, Ado Ekiti, Nigeria \\ 2Department of Medical Biotechnology, National Biotechnology Development Agency, Ogbomoso, Nigeria \\ ${ }^{3}$ Department of Obstetrics and Gynecology, Civil Service Hospital, llorin, Nigeria.
}

[Corresponding Author: E-mail: asufem2017@gmail.com]

\section{ABSTRACT}

This study aimed to demonstrate the effect of honey on the oxidative stress in the brain of sleep-deprived rats. Twenty five 6 weeks old male wistar rats were randomly divided into five groups and subjected to paradoxical sleep deprivation and recovery for 5 days using the modified multiple platform (MMP) method. Group I: Normal control; Group II: sleep deprivation (SD); Group III: sleep deprivation and sleep recovery $(S D+S R)$ - received $10 \mathrm{ml} / \mathrm{kg}$ distilled water orally each; while Group IV: sleep deprivation and honey (SD+Honey) and Group V: sleep deprivation, recovery with honey (SD+SR+Honey) received honey (1 $\mathrm{g} / \mathrm{kg}$ body weight) orally once daily. Brain tissue of the humanely sacrificed rats were excised and homogenized for assessment of oxidative stress markers. Results indicate a significant decrease $(p<0.05)$ in the concentrations of malondialdehyde (MDA) in brain tissues of rats in Groups IV and V when compared with that from sleep deprived group (Group II). The Increase in reduced glutathione (GSH) concentration and catalase enzyme activity observed in homogenized brain tissue of rats in Groups III, IV, and V differ significantly $(p<0.05)$ when compared with Group II. The results suggest that treatment with honey probably has ameliorative effects on oxidative stress in brain tissue of sleep deprived experimental rats.

Keywords: Sleep, Sleep deprivation, Honey, Oxidative stress

\section{INTRODUCTION}

Sleep deprivation (SD) refers to the condition of not been able to achieve sufficient and undisturbed periods of sleep because of environmental or personal reasons (Yongmei et al., 2020). There are a lots of adverse effects associated with SD in humans. They include learning and memory impairment, psychological, physiological and immune dysfunctional effects (Ocalan et al, 2019; Besedovsky et al., 2019). Previous studies revealed that SD causes increased oxidative stress which eventually leads to a series of negative effects, such as cognitive impairment, altered immune status, and increased susceptibility to diseases in the cardiovascular, gastrointestinal and nervous systems (Periasamy et al., 2015; Lungato et al., 2016; Tobaldini et al., 2017). Valvassori et al., (2017) demonstrated that paradoxical sleep deprivation (PSD) in mice increased lipid peroxidation and oxidative damage to DNA and disrupted antioxidant enzymes in certain regions of the brain (frontal cortex, hippocampus).

Oxidative stress is a condition involving an increased rate of cellular damage induced by reactive oxygen species (ROS). ROS are reported to cause alterations in both cell membranes and constituents ending by cell mutation or damage (Yang and Linn, 2002; Juliet et al., 2004). However, the cell defense mechanism against the formation of reactive oxygen species (ROS) involves production of antioxidant enzymes such as catalase (CAT), glutathione reductase (GR) and superoxide dismutase (SOD). The involvement of oxidative stress in the pathogenesis of cognitive impairment has also been reported (Mariani et al., 2005). The role of oxidative stress in many neurodegenerative diseases is not surprising because the brain is rich in fatty acids, consumes a lot of oxygen, and is deficient in endogenous antioxidants. These make it highly susceptible to 


\section{Akintoye et al. Effect of Honey on Oxidative Stress in the Brain Tissue of Sleep Deprived Rats}

reactive oxygen species (ROS) (Uttara et al., 2009).

The brain is deficient in oxidative defense mechanisms and consequently, is at higher risk of damage mediated by (ROS), resulting in cellular dysfunction (Gupta et al., 2003). Oxidative stress has been implicated in the pathophysiological mechanisms involved in brain injury in several common neurodegenerative disorders such as Parkinson's, Alzheimer's, and Huntington's diseases. Several studies have shown polyphenolic compounds present in honey can quench biological reactive oxygen species, counter oxidative stress and restores the antioxidant defense system of cells (Aljadi and Kamaruddin, 2004).

Honey, an insect-derived natural product with curative, cosmetic, traditional and nutritional value (Mohammad et al., 2014) has nootropic properties, such as memory-enhancing as well as neuropharmacological effects, such as antidepressant, anticonvulsant, anxiolytic and antinociceptive activities (Manyi-Loh et al., 2011). It is a good source of physiologically active polyphenols with antioxidant properties (Islam et al., 2012). To the best of our knowledge, there is no study to date that has demonstrated the effect of honey on sleep deprivation and recovery in experimental animals. Hence, this study was designed to investigate ameliorative effects of honey on the induced oxidative stress status in the brain of sleep - deprived rats.

\section{MATERIALS AND METHODS Experimental Animals}

Twenty-five (25) six weeks old Wistar rats weighing between $180-200 \mathrm{~g}$ were purchased from Ekiti State University, Ado -Ekiti, Ekiti-State, Nigeria, and used for the study. They were housed and maintained in standard conditions of light, feeding, and temperature in the animal house of College of Medicine, Ekiti State University, Ado -Ekiti, Ekiti-State, Nigeria.

\section{Honey}

Honey was purchased from the Department of Agriculture at Ekiti State University, Ado Ekiti, Ekiti State Nigeria. The honey was diluted with distilled water (1:1 v/v).

\section{Experimental Design}

The experimental protocol was approved by the Ekiti State University, with protocol number EKSU/A67/2019/02/008. Rats were acclimatized for seven days after which the rats were randomly assigned to one of the following experimental groups ( $\mathrm{n}=5$ per group) and treated accordingly: Rats in Group I (Control) received distilled water $(10 \mathrm{ml} / \mathrm{kg}$, orally) daily. Rats in Group II received distilled water (10 $\mathrm{ml} / \mathrm{kg}$, orally) daily; designated as sleep deprived (SD) group. Rats in group III received distilled water (10 ml/kg, orally) daily; designated as sleep deprived and recovery (SD + SR) group. Group IV received honey (1 $\mathrm{g} / \mathrm{kg}$ body weight, orally) daily; designated as sleep deprived with honey administration $(\mathrm{SD}+\mathrm{H})$. Group V received honey ( $1 \mathrm{~g} / \mathrm{kg}$ body weight, orally) daily; designated as sleep deprived and sleep recovery with honey administration $(S D+S R+H)$.

\section{Sleep Deprivation Model}

Except for the control group (Group I), all other experimental rats were subjected to paradoxical sleep deprivation for 20 hours (11:00 am - 7:00 am next morning) for 5 days with 4 hours (7:00 am-11:00 am) rest each day using the modified multiple platform (MMP) method as described by Oh et al. (2012). Briefly, the rats were placed in an acrylic water tank $(123 \times 44 \times 44 \mathrm{~cm})$ containing 14 circular platforms, $6.5 \mathrm{~cm}$ in diameter, with water up to $1 \mathrm{~cm}$ of their upper surface. Thus, the rats could move around inside the tank by jumping from one platform to another. When they reached the P- phase of sleep, muscle atonia set in, and they fell into the water and woke up. Rats were exposed to a $12 \pm 1$ hour light-dark cycle to circadian rhythm throughout the experimental period and had unrestricted access to standard rat chow by placing chow pellets and water bottles on a grid located on top 


\section{Nigerian Journal of Basic and Applied Science (June, 2021), 29(1): 83-89}

of the tank. Daily change of water in the tank was also ensured. For the sleep recovery model, after 5 days of sleep deprivation, the animals in groups III and V were given a sleep recovery period of 5 days and they were transported to cages where they were allowed to sleep freely (Hipolide et al., 2006) but received distilled water and honey supplement, respectively.

\section{Determination of Biochemical Parameters}

The rats were anaesthetized using a mixture of $25 \% \quad(\mathrm{w} / \mathrm{v})$ urethane and $1 \%(\mathrm{w} / \mathrm{v})$ alpha chloralose (5 ml/kg; Intraperitoneal (i.p), BDH Chemicals Ltd., Poole, England). The animals were humanely sacrificed and brain tissues were quickly excised and weighed. Thereafter, they were washed in cooled $0.15 \mathrm{M} \mathrm{NaCl}$ and were then homogenized in $2 \mathrm{ml}$ of ice-cold potassium phosphate buffer $(0.1 \mathrm{M}, \mathrm{pH}: 7.4)$ using an improvised homogenizer. Samples were centrifuged at $5000 \mathrm{rpm}$ for $15 \mathrm{~min}$ to obtain the supernatant which was stored at $-20^{\circ} \mathrm{C}$ and later used to assay for markers of oxidative stress.

\section{Determination of Malondialdehyde Level}

Malondialdehyde (MDA) was indirectly estimated by determining the accumulation of thiobarbituric acid reactive substances (TBARS) based on the method of Mihara and Uchiyama, (1978). Briefly, $3 \mathrm{ml}$ of $1 \% \mathrm{H}_{3} \mathrm{PO}_{4}$ and $1 \mathrm{ml}$ of $0.6 \%$ TBA aqueous solution were added to $0.5 \mathrm{ml}$ of $10 \%$ tissue homogenate. The mixture was stirred, then heated on a boiling water bath for 45 minutes and allowed to cool, after which $4 \mathrm{ml}$ of $\mathrm{n}$-butanol was added, shaken and the butanol layer was separated by centrifugation. The concentration of MDA (nmol/ml) was calculated by using the following formula:

Concentration of the test = $\frac{\text { Absorbance (test) - Absorbance (blank) }}{\text { Extinction Coefficient (test) }} \times 1000000$

\section{Determination of Glutathione (GSH) Level}

Reduced glutathione was assayed according to the method of Ellman, (1959). Exactly $0.5 \mathrm{~g}$ of tissue was rinsed with phosphate buffer solution. It was homogenized in $2.5 \mathrm{ml}$ protein precipitation reagent and centrifuged at $3000 \mathrm{rpm}$ for 10 minutes and the supernatant collected. To $100 \mu$ of standard and samples in microcuvettes, $880 \mu \mathrm{GSH}$ dilution buffer and $20 \mu \mathrm{GSH}$ Chromogen were added then mixed. A standard curve was plotted using the absorbance values read at $415 \mathrm{~nm}$ against prepared concentrations of GSH standards. This was used to extrapolate GSH concentrations in the samples and expressed as $\mu$ mole of $\mathrm{GSH} / \mathrm{g}$ protein.

\section{Determination of Catalase Activity}

CAT activity was assayed by $\mathrm{H}_{2} \mathrm{O}_{2}$ consumption following the method of Aebi (1984). Briefly, 100 $\mu \mathrm{l}$ of tissue extract with an equal volume of absolute alcohol was incubated for $30 \mathrm{~min}$ in an ice bath for degradation of the inactive CAT$\mathrm{H}_{2} \mathrm{O}_{2}$ complex II to release active CAT enzyme. After 30 min on ice, the tubes were brought back to room temperature and then $10 \mu$ of Triton X100 was added. In a cuvette containing $200 \mu$ of phosphate buffer, $50 \mu \mathrm{l}$ of tissue extract and 250 $\mu \mathrm{l}$ of $0.066 \mathrm{M} \mathrm{H}_{2} \mathrm{O}_{2}$ in phosphate buffer were added and the decrease in absorbance was read at $240 \mathrm{~nm}$ for $30 \mathrm{~s}$. A molar absorptivity of $43.6 \mathrm{M}$ $\mathrm{cm}^{-1}$ was used to determine CAT activity defined as one unit is equal to the $\mu$ moles of hydrogen peroxide degraded per minute per mg of protein. One catalase unit is equivalent to 0.01 decrease in absorbance at $240 \mathrm{~nm} / \mathrm{mg}$ protein/min. Catalase activity is thus expressed as (Decrease in absorbance $x$ 100/1) divided by protein amount in $\mathrm{mg}$ divided by time in $\mathrm{min}=u$ it $/ \mathrm{mg}$ protein/min.

\section{Statistical Analysis}

Data are expressed as mean \pm standard deviation (SD). Test of variance was done using ANOVA, followed by Newman-keuls multiple comparisons test. Statistically significant differences were compared at $p<0.05$. Statistical analysis was performed using Graph - Pad (Prism 7) statistical software.

\section{RESULTS}

Result presented in Table 1 show an increase in brain weight $(p<0.05)$ among rats in groups I, III, 


\section{Akintoye et al. Effect of Honey on Oxidative Stress in the Brain Tissue of Sleep Deprived Rats}

$\mathrm{IV}$, and $\mathrm{V}$ (ranging between $1.82 \pm 0.02-1.91 \pm$ $0.02 \mathrm{~g}$ ) when compared with group II.

Table 1: Effects of honey on brain weight in sleep-deprived wistar rat

\begin{tabular}{ll}
\hline GROUP & BRAIN WEIGHT (g) \\
\hline Group I & $1.79 \pm 0.01$ \\
Group II & $1.68 \pm 0.03^{\mathrm{a}}$ \\
Group III & $1.82 \pm 0.02^{\mathrm{b}}$ \\
Group IV & $1.88 \pm 0.02^{\mathrm{b}}$ \\
Group V & $1.91 \pm 0.02^{\mathrm{b}}$ \\
\hline
\end{tabular}

Results are expressed as Mean \pm SD of 5 rats per group. Values with different superscripts are significantly different $(p<0.05)$. Group I: Normal control; Group II: Sleep deprived ;Group III : Sleep deprived and sleep recovery; Group IV : Sleep deprived and honey treated; Group V : Sleep deprived, sleep recovery and honey treated.

As shown in Table 2, the levels of GSH of group II and group III differ significantly $(p<0.05)$ when compared with group I. Similarly, GSH concentrations in groups III, IV and V increased significantly $(p<0.05)$ when compared with group II. The result also shows a significant difference $(p<0.05)$ in the MDA concentrations of the rats in groups II and III when compared with the control. However, there was a significant difference $(p<0.05)$ in the concentrations of MDA between group IV and V when compared with group II.

Table 2: Effects of honey on brain tissue Reduced glutathione levels in sleep-deprived wistar rat

\begin{tabular}{lll}
\hline GROUP & $\begin{array}{l}\text { BRAIN TISSUE } \\
\text { GSH }(\mu \mathrm{mole} / \mathrm{g} \\
\text { protein) }\end{array}$ & $\begin{array}{l}\text { Brain Tissue } \\
\text { MDA } \\
\text { (ng/mg protein) }\end{array}$ \\
\hline Group I & $1.41 \pm 0.04$ & $29.48 \pm 1.57$ \\
Group II & $1.08 \pm 0.05^{\mathrm{a}}$ & $40.71 \pm 1.94^{\mathrm{a}}$ \\
Group III & $1.21 \pm 0.04^{\mathrm{b}}$ & $35.76 \pm 1.71^{\mathrm{b}}$ \\
Group IV & $1.34 \pm 0.04^{\mathrm{c}}$ & $27.52 \pm 1.54^{\mathrm{c}}$ \\
Group V & $1.32 \pm 0.03^{\mathrm{c}}$ & $28.94 \pm 0.93^{\mathrm{c}}$ \\
\hline
\end{tabular}

Results are expressed as Mean \pm SD of 5 rats per group. Values with different superscripts are significantly different $(p<0.05)$. Group I: Normal control; Group II : Sleep deprived ;Group III :
Sleep deprived and sleep recovery; Group IV Sleep deprived and honey treated; Group V : Sleep deprived, sleep recovery and honey treated.

The results of effects of honey on brain catalase activity in sleep - deprived wistar rats are presented in Table 3 shows no difference $(p>0.05)$ in catalase activities of brain tissue homogenate obtained from animals in groups III, IV and $\mathrm{V}$ but the observed catalase activities in these groups were significantly different $(p<0.05)$ compared with that observed for group II samples.

Table 3: Effects of honey on brain tissue catalase activity in sleep-deprived wistar rat

\begin{tabular}{ll}
\hline Group & \multicolumn{1}{c}{$\begin{array}{c}\text { BRAIN CATALASE } \\
\text { (nmol of } \mathrm{H}_{2} \mathrm{O}_{2} / \mathrm{min} / \mathrm{mg} \text { protein) }\end{array}$} \\
\hline Group I & $42.11 \pm 1.00$ \\
Group II & $20.49 \pm 2.04^{\mathrm{a}}$ \\
Group III & $33.13 \pm 2.26^{\mathrm{b}}$ \\
Group IV & $36.07 \pm 0.89^{\mathrm{b}}$ \\
Group V & $36.87 \pm 4.41^{\mathrm{b}}$ \\
\hline
\end{tabular}

Results are expressed as Mean \pm SD of 5 rats per group. Values with different superscripts are significantly different $(p<0.05)$. Group I :Normal control; Group II : Sleep deprived ;Group III : Sleep deprived and sleep recovery; Group IV : Sleep deprived and honey treated; Group V : Sleep deprived, sleep recovery and honey treated.

\section{DISCUSSION}

Sleep deprivation is a potent oxidative stressor that could cause alteration in behavior and cognitive performance. A bidirectional relationship between sleep deprivation and oxidative stress has been documented (Hill et al., 2018). Findings in this study demonstrated a significant decrease in the GSH level and CAT activity and an elevated level of MDA among rats in the SD group when compared with rats in other groups. Karem et al. (2015) showed that the hippocampus is susceptible to free radical 


\section{Nigerian Journal of Basic and Applied Science (June, 2021), 29(1): 83-89}

damage following sleep deprivation as evidenced by a decrease in GSH levels in the region.

The decrease in GSH levels in the SD group confirms the fact that sleep deprivation induced the generation of free radicals and depleted the activities of antioxidant enzymes in the brain. GSH plays multiple roles as a cellular antioxidant defense because its main function is to remove hydrogen peroxide and organic peroxides (Antunes and Brito, 2017). Therefore, decline in the level of GSH may indicate the increased production of free radicals (Debnath and Mandal, 2000). In contrast, Singh et al., 2008 noticed that sleep deprivation did not affect oxidative stress parameters in the striatum; and the activity of glutathione peroxidase was not affected in any of the studied brain regions. The disparity between this report and ours may be attributed to differences in the age of animals and method of sleep deprivation used. Nermin et al. (2020) showed that sleep deprivation in an animal model is associated with the altered status of brain oxidative stress. Lipid peroxidation due to the reaction of free radicals with lipids is considered a hallmark of cellular oxidative damage. Once established, such damage can affect the membrane lipid bilayer and, specifically, the mitochondrial electron transport chain, thus becoming a major cause for a further increase in oxidant production. Studies reported that SD induced oxidative processes in several types of tissues, resulting in some cases, in cognitive impairment and behavioral changes (Lungato et al., 2013). For instance, Everson et al. (2005) also showed in their study a significant decrease in liver CAT activity in sleep-deprived rats.

The present study provides evidence that sleep recovery restores or promotes antioxidants and antioxidant activities in the brain. The significant increase in GSH level, CAT activity and significant decrease in the MDA level in honey treated groups compared to SD group may be due to the ability of honey to promote the activity of antioxidant enzymes (Abdulmajeed et al., 2016). The phenolic acids and flavonoids are responsible for the well-established antioxidant activity of honey. The exact antioxidant mechanism is unknown, but the proposed mechanisms include free radical sequestration and metallic ion chelation (Mohammed et al., 2015). Antioxidants protect brain cells from oxidative stress; thereby reducing brain damage and improved neuronal functions. Honey decreased the number of degenerated neuronal cells in the hippocampal CA1 region, a region that is known to be highly susceptible to oxidative insult (Cai et al., 2011). This may be as a result of the presence of ellagic acid in honey (Uzar et al., 2012). Ellagic acid is a phenolic acid that is found in fruits, vegetables and also in honey. Ellagic acid has antioxidant activity and also shows chemo-preventive effects, as indicated by its antiproliferative activity (Seeram et al., 2005). Interestingly, the chemo-preventive effects of ellagic acid are executed through the reduction of oxidative stress at the cellular level (Nurul et al., 2012); Treatment with ellagic acid, present in honey also restores the activities of catalase and the total antioxidant status of the brain to normal levels (Uzar et al., 2012).

\section{CONCLUSION}

In conclusion, honey significantly improved brain oxidative status and has ameliorative effect on oxidative stress in the brain of sleep deprived rats.

\section{ACKNOWLEDGEMENTS}

We duly acknowledge the Management of Ekiti State University Teaching Hospital, Ekiti for their immense support and assistance during the course of this research.

\section{REFERENCES}

Abdulmajeed, W. I., Sulieman, H. B., Zubayr, M. O., Imam, A., Amin, A. \& Biliaminu, S.A. (2016). Honey prevents neurobehavioural deficit and oxidative stress induced by lead acetate exposure in male Wistar rats - A preliminary study. Metabolic Brain Dieases, 31(1): 37-44. 


\section{Akintoye et al. Effect of Honey on Oxidative Stress in the Brain Tissue of Sleep Deprived Rats}

Aebi, H. (1984). Catalase in vitro, Methods in Enzymology. Elsevier Journal, 105: 121126

Aljadi, A.M. \& Kamaruddin, M.Y. (2004.)."Evaluation of the phenolic contents and antioxidant capacities two Malaysian floral honeys," Food Chemistry, 85 (4): 513-518.

Antunes, F. \& Brito, P.M. (2017).Quantitative biology of hydrogen peroxide signaling.Redox Biology; 13: 1-7.doi 10.1016 / j. redox. 2017.04 .039

Besedovsky, L., Lange, T. \& Haack, M.(2019)."The sleep-immune crosstalk in health and disease," Physiological Reviews, 99(3):1325-1380.

Cai, M., Shin, B.Y. \& Kim, D.H.(2011). "Neuroprotective effects of a traditional herbal prescription on transient cerebral global ischemia in gerbils," Journal of Ethnopharmacology, 138(3): 723-730.

Debnath, D. \& Mandal, T.K. (2000). Quinalphos (an environmental oestrogenic insecticide) formulation (Ekalux $25 \mathrm{E}$. C.) induced damage of the testicular tissues and antioxidant defense systems in Sprague-Dawley albino rats. Journal of Applied Toxicology,20: 197-04.

Ellman, G.L. (1959). Tissue sulfhydryl groups.Archive of Biochemistry andBiophysics,82: 70-77.

Everson, C.A., Laatsch, C.D. \& Hogg, N. (2005).Antioxidant defense responses to sleep loss and sleep recovery.American Journal of Physiology, 288:374-83.

Gupta, Y.K., Gupta, M. \& Kohli, K.(2009). Neuroprotective role of melatonin in oxidative stress vulnerable brain.Indian Journal of Physiology and Pharmacology, 47:373-86.

Hill, V.M., O'Connor, R.M., Sissoko, G.B., Irobunda, I.S., Leong, S., Canman, J.C., Stavropoulos, N. \& Shirasu-Hiza, M.(2018). A bidirectional relationship between sleep and oxidative stress in drosophila. Public Library of Science,Biololgy, 16(7): e2005206.
Hipolide, D. C., Suchecki, D., Pimentel de Carvalho Pinto, A., Chiconelli, E. F., Tufik, S.\& Luz, J. (2006).Paradoxical sleep deprivation and sleep recovery: Effects on the Hypothalamic- PituitaryAdrenal Axis activity, energy balance and body composition of rats. Journal of Neuroendocrinology, 18(4): 231-8.

Islam, A., Khalil, M. I. \& Islam M.N. (2012). Physicochemical and antioxidant properties of Bangladeshi honeys stored for more than one year.Complementary and Alternative Medicine, 12: 177.

Juliet, P.A., Hayashi, T., Daigo, S., Matsui-Hirai, H., Miyazaki, A., Fukatsu, A., Funami, J., Iguchi, A. \& Ignarro, L.J. (2004). The combined effect of testosterone and apocynin on nitric oxide and superoxide production in PMA-differentiated THP-1 cells.Biochimical.Biophysica.Acta BBAMolecular Cell Research,1693: 185-191.

Karem, H. A., Fadia, A. M., Omar, F. K., Fatima, M. B., Farah, H. A. \& Nizar, M. M. (2015). Chronic melatonin treatment prevents memory impairment induced by chronic sleep deprivation. Molecular Neurobiology, DOI: 10.1007/s12035-0159286-z

Lungato, L., Nogueira-Pedro, A., Carvalho Dias, C., Paredes-Gamero, E.J., Tufik, S. \& D'Almeida, V. (2016). Effects of sleep deprivation on mice bone marrow and spleen B lymphopoiesis. Journal of Cellular Physiology, 231(6): 1313-1320.

Lungato, L., Marques, M.S., Pereira, V.G., Hix, S., Gazarini, M.L., Tufik, S. \& D'Almeida, V. (2013). Sleep deprivation alters gene expression and antioxidant enzyme activity in mice splenocytes. Scandinavian Journal of Immunology, 77:195-9.

Manyi-Loh, C. E., Clarke, A. M. \& Ndip R. N., (2011).An overview of honey: therapeutic properties and contribution in nutrition and human health. African Journal of Microbiology Research, 5(8): 844-852. 


\section{Nigerian Journal of Basic and Applied Science (June, 2021), 29(1): 83-89}

Mariani, E., Polidori, M. C., Cherubini, A. \& Mecocci, $P .(2005)$. Oxidative stress in brain aging, neurodegenerative and vascular diseases: an overview. Journal of Chromatography: Analytical Technologies in the Biomedical and Life Sciences, 827(1): 65-75.

Mihara and Uchiyama, (1978)" not listed in the reference list has been provided as: Mihara M, and Uchiyama M. (1978). Determination of malondialdehyde precursor in tissues by isobarbituric acid test. Anal Biochem; 86:271-278.

Mohammad, M. R., Siew, H. G. \& Ibrahim, K. (2014). Neurological Effects of Honey: Current and Future prospects. Hindawi Publishing Corporation Evidence-Based Complementary and Alternative Medicine, Volume Article ID 958721, 13 pages, DOI $/ 10.1155 / 2014 / 958721$

Mohammed, S. S., Blossom, B. \& Ashadevi, S. (2015). Antioxidant activity, DNA and cellular protective effect of honey from Srilanka. Asian Journal of Biochemistry, 10:106 - 116

Nermin, I., Rizk, Mohamed, S., Rizk \& Asmaa, S. (2020). Attenuation of sleep deprivation dependent deterioration in male fertility parameters by vitamin C. Reproductive Biology and Endocrinology, 18:2

Nurul, S., Gan, S., Halim, A., Shah, A., \& Sukari, H.(2012). Analysis of volatile compounds of Malaysian Tualang (Koompassiaexcelsa) honey using gas chromatography-mass spectrometry. African Journal of Traditional, Complementary and Alternative Medicines, 10(2): 180-188.

Ocalan, B., Cakir, A., Koc, C., Suyen, G. G. \& Kahveci, N.(2019). Uridine treatment prevents REM sleep deprivation-induced learning and memory impairment.Neuroscience Research, 148: 42-48.

Oh, M.M., Kim, J.W., Jin, M.H., Kim, J.J. \& Moon, D.G. (2012). Influence of paradoxical sleep deprivation and sleep recovery on testosterone level in rats of different ages. Asian Journal of Andrology, 14: 330-334.

Periasamy, S., Hsu, D. Z., Fu, Y. H. \& Liu, M. Y. (2015).Sleep deprivation-induced multiorgan injury: role of oxidative stress and inflammation. Experimental and Clinical Sciences Journal, 14 : 672- 683.
Seeram, N. P., Adams, L. S. \& Henning, S. M. (2005). In vitro antiproliferative, apoptotic and antioxidant activities of punicalagin, ellagic acid, and a total pomegranate tannin extract are enhanced in combination with other polyphenols as found in pomegranate juice.The Journal of Nutritional Biochemistry, 16: (6) 360-367.

Singh, R., Kiloung, J., Singh, S. \& Sharma, D. (2008). Effect of paradoxical sleep deprivation on oxidative stress parameters in brain regions of adult and old rats.Biogerontology Journal, 9(3):153-62

Tobaldini, E., Costantino, G. \& Solbiati, M. (2017). Sleep, sleep deprivation, autonomic nervous system and cardiovascular diseases. Neuroscience and Biobehavioral Reviews ,74: 321-329.

Uttara, B., Singh, A.V., Zamboni, P. \& Mahajan, R.T. (2009). Oxidative stress and neurodegenerative diseases: a review of upstream and downstream antioxidant therapeutic options. Current Neuropharmacology, 7(1):65-74

Uzar, E., Alp, H., Cevik, M. U. (2012). Ellagic acid attenuates oxidative stress on brain and sciatic nerve andimproves histopathology of brain in streptozotocin-induced diabetic rats. Neurological Sciences, 33 (3): 567-574.

Valvassori, S. S., Resende, W.R. \& Dal-Pont, G.(2017). Lithium ameliorates sleep deprivation-induced mania-like behavior, hypothalamic-pituitary-adrenal (HPA) axis alterations, oxidative stress and elevations of cytokine concentrations in the brain and serum of mice.Bipolar Disorders, 19(4): 246258.

Yang, C.Y. \& Lin, M.T. (2002). Oxidative stress in rats with heat stroke induced cerebral ischemia. Stroke 33:790-794.

Yongmei, L., Yuan, Z., Guang, J., Yiwei, S., Nan, Z.,Yuhan, L., Zihan, W., Mengqi, L. \& Laixiang, L. (2020). Autophagy Triggered by Oxidative Stress appears to be mediated by the AKT/ Mtor signaling pathway in the Liver of Sleep- Deprived Rats.Oxidative Medicine and Cellular Longevity, 2020: 6181630 